Diskursus: Jurnal Pendidikan Bahasa Indonesia

Vol. 3, No. 3, Desember 2020, pp. 240-249

p-ISSN: 2615-4935

e-ISSN: 2615-4943

\title{
Kesalahan Penggunaan Taksonomi Siasat Permukaan dan Ejaan dalam Happy Love Guide Karya Jose Aditya
}

\author{
Marissa Fitrisia Aswara \\ Universitas Indraprasta PGRI \\ Jalan Nangka No. 58 C/TB. Simatupang, Tanjung Barat, Jakarta Selatan 12530 \\ E. Zaenal Arifin \\ Universitas Indraprasta PGRI \\ Jalan Nangka No. 58 C/TB. Simatupang, Tanjung Barat, Jakarta Selatan 12530 \\ Gustaman Saragih \\ Universitas Indraprasta PGRI \\ Jalan Nangka No. 58 C/TB. Simatupang, Tanjung Barat, Jakarta Selatan 12530 \\ marissafitri19@gmail.com
}

\begin{abstract}
This research aims to analyze taxonomic and spelling errors in Jose Aditya's Happy Love Guide guidebook to reveal how many errors are contained in this manual. The research methods used are content analysis in which there are efforts to decide the purpose, define terms, specialize the units to be analyzed, search for relevant data, build conceptual relationships, plan sample withdrawals, and conduct category coding that is done objectively and systematically. The data collection technique used is a tapping technique, namely tapping data errors contained in the book Happy Love Guide. The data analysis technique used is a technique with a basic technique for direct elements and the advanced technique used is the technique of transforming the form by reconstructing sentences. The results of this study found 42 pieces of taxonomic error data with the following details: (1) the addition of 18 pieces of data, (2) the formation of 15 pieces of data, (3) the omission of 7 pieces of data, and (4) the sequencing of 2 pieces of data. Meanwhile, 45 pieces of spelling error data were found with the following details: (1) word writing as many as 22 pieces of data, (2) the use of punctuation as much as 9 pieces of data, (3) the use of italics as much as 5 pieces of data, (4) the use of capital letters as much as 4 pieces of data, (5) the use of the absorption element of 3 pieces of data, (6) the use of the symbol of the number of 2 pieces of data, and (7) there are no errors in the word of syllabification.
\end{abstract}

Keywords: Language Errors, Surface Tactic Taxonomy, Spelling, Happy Love Guide book.

\begin{abstract}
Abstrak
Penelitian ini bertujuan untuk menganalisis kesalahan penggunaan taksonomi dan ejaan dalam buku panduan Happy Love Guide karya Jose Aditya untuk mengungkapkan seberapa banyak kesalahan yang terdapat dalam buku panduan ini. Metode penelitian yang digunakan adalah analisis isi yang didalamnya terdapat upaya memutuskan tujuan, mendefinisikan istilah-istilah, mengkhususkan unit yang akan dianalisis, mencari data yang relevan, membangun hubungan konseptual, merencanakan penarikan sampel, dan melakukan pengodean kategori yang dilakukan secara objektif dan sistematis. Teknik pengumpulan data yang digunakan adalah teknik sadap, yakni menyadap kesalahan data yang terdapat dalam buku Happy Love Guide. Teknik analisis data yang digunakan adalah teknik agih dengan teknik dasar bagi unsur langsung dan teknik lanjutan yang digunakan adalah teknik pengubahan wujud dengan merekonstruksi kalimat. Hasil penelitian ini ditemukan 42 buah data kesalahan taksonomi siasat permukan dengan rincian sebagai berikut: (1) penambahan sebanyak 18 buah data, (2) pembentukan sebanyak 15 buah data, (3)
\end{abstract}


penghilangan sebanyak 7 buah data, dan (4) pengurutan sebanyak 2 buah data. Sementara itu, ditemukan 45 buah data kesalahan ejaan dengan rincian sebagai berikut: (1) penulisan kata sebanyak 22 buah data, (2) penggunaan tanda baca sebanyak 9 buah data, (3) penggunaan huruf miring sebanyak 5 buah data, (4) penggunaan huruf kapital sebanyak 4 buah data, (5) penggunaan unsur serapan sebanyak 3 buah data, (6) penggunaan lambang bilangan sebanyak 2 buah data, dan (7) tidak ada kesalahan pada pemenggalan kata.

Kata kunci: Kesalahan Berbahasa, Taksonomi Siasat Permukaan, Ejaan, Buku Panduan Happy Love Guide

\section{PENDAHULUAN}

Bahasa Indonesia memiliki fungsi sebagai alat komunikasi yang paling utama bagi masyarakat Indonesia. Namun, masih banyak masyarakat Indonesia yang mengalami kesalahan dalam berbahasa, terutama dalam keterampilan menulis. Tak hanya pelajar, terkadang kesalahan penulisan sering terjadi oleh orang dewasa.

Berbicara mengenai berbahasa, maka tak luput dari kesalahan dalam berbahasa. Kesalahan berbahasa adalah suatu penggunaan bahasa yang tidak sesuai dengan kaidah bahasa Indonesia, baik secara lisan maupun tertulis. Kesalahan biasanya berasal dari diri penulis itu sendiri. Kesalahan yang terjadi karena faktor kelelahan, kelalaian, atau ketidaktahuan penulis terhadap tata bahasa apalagi tata bahasa baku bahasa Indonesia.

Istilah kesalahan berbahasa merupakan padanan dari kata errors yang bersinonim dengan kata mistake dan goofs. Hal inilah yang melatarbelakangi peneliti mengadakan penelitian mengenai kesalahan berbahasa dalam sebuah buku panduan kehidupan romansa karya Jose Aditya. Apakah kesalahan yang terjadi karena faktor penyimpangan, pelanggaran, atau kekhilafan? Berkait dengan hal itu, peneliti menemukan banyak kesalahan dalam tata bahasa, diksi, ejaan, dan penulisan dalam buku Happy Love Guide karya Jose Aditya. Hal itulah yang membuat peneliti tertarik untuk meneliti lebih lanjut buku tersebut dan ingin mengetahui seberapa banyak kesalahan yang terdapat didalamnya.

Buku merupakan buah pikiran berisi ilmu pengetahuan hasil analisis terhadap sesuatu hal secara tertulis. Dalam hal ini, peneliti akan menggunakan buku panduan kehidupan romansa Happy Love Guide karya Jose Aditya yang terbit tahun 2020.

Analisis kesalahan berbahasa adalah suatu kegiatan yang mengkritik, memperbaiki, dan mengumpulkan suatu data kesalahan berbahasa, serta mengklasifikasikan sesuai bidangnya. Serupa dengan pendapat Ellis (dalam Tarigan, 2011:170) yang mengatakan bahwa analisis kesalahan berbahasa merupakan suatu prosedur yang digunakan oleh peneliti yang meliputi pengumpulan sampel, pengidentifikasian kesalahan yang terdapat dalam sampel, penjelasan kesalahan tersebut, pengklasifikasian kesalahan itu berdasarkan penyebabnya, serta pengevaluasian atau penilaian taraf keseriusan kesalahan itu. Dengan demikian, dapat dipahami dan diungkapkan berbagai kesalahan yang terdapat dalam buku panduan tersebut.

Kesalahan berbahasa ragam tulis yang dimaksud dalam penetitian ini adalah kesalahan pada taksonomi siasat permukaan dan ejaan. Berbicara 
mengenai taksonomi kesalahan berbahasa, terdapat empat taksonomi yang perlu kita ketahui, yaitu (1) taksonomi kategori linguistik, (2) taksonomi siasat permukaan, (3) taksonomi komparatif, dan (4) taksonomi efek komunikatif (Tarigan, 2011:129).

Sementara itu, ejaan adalah sebuah ilmu yang mempelajari pengucapan atau ujaran oleh seseorang yang ditulis dengan perantara lambang-lambang atau gambar-gambar bunyi. Senada dengan itu, Suryaman (dalam Rahayu, 2007:15) menyatakan bahwa ejaan adalah keseluruhan peraturan dalam melambangkan bunyi-bunyi ujaran, menempatkan tanda baca, memotong suku kata, dan menghubungkan kata-kata. Kaidah ejaan dalam tata bahasa tulis sangat penting karena dapat menimbulkan kesalahpahaman apabila tidak dimengerti oleh pembaca. Dalam penelitian ini, kesalahan ejaan yang diteliti adalah kesalahan dalam penggunaan huruf kapital, huruf miring, penulisan kata, unsur serapan, lambang bilangan, tanda baca, dan pemenggalan kata.

Berkenaan dengan uraian tersebut, penelitian ini mengkaji kesalahan taksonomi dan ejaan dalam Happy Love Guide karya Jose Aditya. Penggunaan bahasa yang ringan dan disesuaikan dengan gaya bahasa zaman sekarang, serta tanpa memperhatikan kaidah penulisan sehingga menyebabkan banyak kesalahan dalam penulisan. Hal itulah yang mendorong peneliti melakukan penelitian lebih lanjut terhadap kesalahan taksonomi dan ejaan pada konteks tertulis.

\section{METODE}

Penelitian ini menggunakan metode analisis isi (content analysis). Fraenkel dan Wallen (2007:483) menyatakan analisis isi adalah teknik yang dapat digunakan peneliti untuk mengkaji perilaku manusia secara tidak langsung melalui analisis terhadap komunikasi mereka, seperti buku teks, esai, Koran, novel, artikel majalah, lagu, gambar iklan, dan semua jenis komunikasi yang dapat dianalisis.

Dalam penelitian ini, teknik pengumpulan data yang dilakukan adalah teknik simak dan catat. Metode simak dilakukan dengan menyimak kesalahan berbahasa pada kategori taksonomi siasat permukaan dan ejaan dalam bentuk tulisan. Teknik dasar yang digunakan dalam metode simak adalah teknik sadap. Teknik sadap adalah teknik penyediaan data yang diwujudkan dengan penyadapan, atau dengan kata lain mengambil data yang ada dalam suatu konteks (Sudaryanto, 1993:13). Dalam hal ini, peneliti menyadap data dalam buku panduan romansa Happy Love Guide karya Jose Aditya. Setelah menyimak, peneliti menggunakan teknik lanjutan berupa teknik catat. Pencatatan dapat dilakukan melalui korpus data yang segera dilanjutkan dengan klasifikasi.

Pada tahap analisis data dilakukan upaya mengelompokkan data berdasarkan kategorinya, yakni dengan menggunakan metode agih sebagai teknik analisis data. Dalam metode agih alat penentunya berasal dari bahasa itu sendiri. Teknik lanjutan yang peneliti gunakan adalah teknik pengubahan wujud dengan melakukan interpretasi berupa merekonstruksi kalimat. Untuk menghindari kesalahan atau kekeliruan data yang telah terkumpul, perlu dilakukan pengecekan 
validitas atau keabsahan data dengan kredibilitas, transferabilitas, dependabilitas, dan konfirmabilitas.

\section{HASIL DAN PEMBAHASAN}

\section{Landasan Teori}

\section{Hakikat Kesalahan Berbahasa}

Kesalahan merupakan suatu hal yang wajar terjadi saat belajar bahasa. Hal ini sejalan dengan pendapat Dulay (dalam Mintowati, 2010:53) bahwa orang tidak mungkin dapat mempelajari bahasa tanpa membuat kesalahan. Kesalahan yang terjadi biasanya disebabkan oleh beberapa faktor, salah satunya adalah faktor internal seperti fisik dan mental si penutur. Berkenaan dengan itu, Sharma (dalam Hastuti, 2003:79) menyatakan bahwa kesalahan mungkin disebabkan oleh sejumlah faktor ekstra linguistik, seperti kegagalan ingatan, emosi yang meningkat, dan kelelahan mental atau fisik.

Analisis kesalahan berbahasa merupakan suatu cara untuk mengidentifikasi kesalahan berbahasa seseorang. Melalui kegiatan analisis kesalahan berbahasa tersebut, kita dapat mengetahui kesalahan-kesalahan apa saja yang tidak sesuai kaidah kebahasaan. Berkenaan dengan itu, Tarigan (2011:25) memaparkan bahwa analisis kesalahan berbahasa adalah suatu prosedur kerja yang biasa digunakan oleh peneliti atau guru bahasa dengan melakukan kegiatan seperti mengumpulkan sampel kesalahan, mengidentifikasi kesalahan pada sampel, menjelaskan kesalahan itu, mengklasifikasikannya, dan mengevaluasi taraf keseriusan kesalahan itu.

Menurut Setyawati (2010:16) terdapat tiga kemungkinan seseorang dapat salah dalam berbahasa, yakni (a) terpengaruh bahasa yang lebih dahulu disukainya, (b) kekurangpahaman pemakai bahasa terhadap bahasa yang dipakainya, dan (c) pengajaran bahasa yang kurang tepat atau kurang sempurna. Sejalan dengan pendapat tersebut, Corder (dalam Setiyaningsih, 2014) mengemukakan tiga alasan terjadinya kesalahan berbahasa, yakni (1) kesalahan dalam pentransferan, (2) kesalahan analogis, dan (3) kesalahan yang diinduksi dari pengajaran yang lemah atau keliru. Tarigan (2011:129) juga memaparkan pembagian kesalahan bahasa pada semua unsur kebahasaan dan aspek penggunaan bahasa. Kesalahan-kesalahan ini dikelompokkan dalam berbagai kategori, yaitu (1) taksonomi kategori linguistik, (2) taksonomi siasat permukaan, (3) taksonomi komparatif, dan (4) taksonomi efek komunikatif.

Kaidah ejaan dalam tata bahasa tulis sangat penting karena dapat menimbulkan kesalahpahaman apabila tidak dimengerti oleh pembaca. Hal itu sejalan dengan pendapat Gantamitreka (2016:179) yang menyatakan bahwa kesalahan ejaan dapat menimbulkan kesalahan tanggapan pembaca terhadap gagasan yang dikemukakan oleh penulis. Berkait dengan itu, Setyawati (2010:156) secara teknis menegaskan bahwa ejaan adalah aturan tulis-menulis dalam suatu bahasa yang berhubungan dengan penulisan huruf, penulisan kata, penulisan unsur serapan, dan penggunaan tanda baca.

\section{Hakikat Buku Panduan/Pedoman}

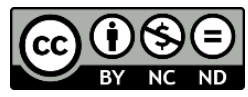


Berbicara mengenai buku, peneliti menggunakan buku panduan/pegangan berjudul Happy Love Guide. Buku panduan biasanya merujuk pada suatu pokok bahasa yang dibahas secara detail dan singkat. Berkenaan dengan itu, Lasa (dalam Irianti, 1998:29) menyatakan bahwa buku pegangan sama dengan buku pedoman atau yang sering disebut manual, yaitu bunga rampai informasi yang dititikberatkan pada suatu subjek atau pokok bahasan.

Fungsi buku panduan menurut Grene dan Petty (dalam Utomo 2008:44), yaitu (1) mencerminkan sudut pandang yang tangguh dan modern mengenai pengajaran/topik yang disajikan, (2) menyajikan suatu sumber pokok masalah atau subject matter yang kaya, (3) menyajikan suatu sumber yang tersusun rapi dan bertahap mengenai keterampilan ekspresional yang mengemban masalah pokok dalam komunikasi, (4) menyaksikan bersama-sama dengan buku manual yang mendampingi metode-metode dan sarana-sarana pengajaran untuk memotivasi siswa, (5) menyajikan fiksasi (perasaan mendalam) awal yang perlu dan juga sebagai penunjang latihan-latihan dan tugas-tugas praktis, dan (6) menyajikan bahan atau sarana/evaluasi dan remedial yang serasi dan tepat guna.

Grene dan Petty (dalam Utomo, 2008:45) memaparkan bahwa ada sepuluh kriteria yang semestinya terdapat dalam buku panduan, yaitu (1) harus menarik minat bagi para siswa yang mempergunakannya, (2) harus mampu memotivasi bagi para siswa yang memakainya, (3) harus memuat ilustrasi yang menarik hati bagi para siswa yang memanfaatkannya, (4) harus mempertimbangkan aspek linguistik sesuai dengan kemampuan para siswa yang memakainya, (5) harus memiliki hubungan erat dengan pelajaran yang lainnya, lebih baik kalau dapat menunjangnya dengan rencana sehingga semuanya menjadi suatu kebulatan utuh dan terpadu, (6) harus dapat menstimulasi dan merangsang aktivitas-aktivitas pribadi siswa yang mempergunakannya, (7) harus dengan sadar dan tegas menghindari konsep-konsep yang samar-samar dan tidak biasa agar tidak sempat membingungkan siswa yang memakainya, (8) harus memiliki sudut pandang atau point of view yang jelas dan tegas sehingga pada akhirnya menjadi sudut pandang.

\section{Hasil}

Data penelitian ini adalah kesalahan taksonomi dan ejaan dalam Happy Love Guide karya Jose Aditya. Data yang didapat sudah melalui tahap pengumpulan sampel, pengidentifikasian kesalahan, penjelasan kesalahan, pengklasifikasian kesalahan, dan pengevaluasian kesalahan berupa merekonstruksi kalimat. Kesalahan yang ditemukan kemudian diklasifikasikan ke dalam kesalahan taksonomi siasat permukaan dan kesalahan ejaan pada pemakaian huruf kapital, huruf miring, kata, unsur serapan, lambang bilangan, tanda baca, penulisan kata, dan pemenggalan kata. Dengan demikian, peneliti akan memaparkan tabel jumlah kesalahan yang ditemukan dalam penelitian ini sesuai dengan tujuan penelitian, yakni sebagai berikut. 
Tabel 1. Kesalahan Taksonomi dan Ejaan dalam Happy Love Guide karya Jose Aditya

\begin{tabular}{ccccccccccccc}
\hline \multirow{3}{*}{ No } & Kode Data & \multicolumn{4}{c}{$\begin{array}{c}\text { Kesalahan } \\
\text { Taksonomi }\end{array}$} \\
\cline { 3 - 18 } & & Ph & Pn & Pb & Pu & HK & HM & PnK & US & LB & TB & PmK \\
1 & B1 & 3 & 7 & - & 1 & 1 & 2 & 7 & 2 & 2 & 4 & - \\
2 & B2 & 2 & 3 & 1 & 1 & - & 1 & 4 & - & - & - & - \\
3 & B3 & 1 & 2 & 3 & - & 1 & 1 & 5 & 1 & - & 1 & - \\
4 & B4 & - & 3 & 11 & - & 2 & 1 & 5 & - & - & 2 & - \\
5 & B5 & 1 & 3 & - & - & - & - & 1 & - & - & 2 & - \\
& Jumlah & $\mathbf{7}$ & $\mathbf{1 8}$ & $\mathbf{1 5}$ & $\mathbf{2}$ & $\mathbf{4}$ & $\mathbf{5}$ & $\mathbf{2 2}$ & $\mathbf{3}$ & $\mathbf{2}$ & $\mathbf{9}$ & $\mathbf{0}$ \\
\hline
\end{tabular}

Dari hasil penelitian ini dapat disimpulkan bahwa dalam buku pedoman/panduan Happy Love Guide karya Jose Aditya memiliki beberapa kesalahan penulisan. Dari kesalahan taksonomi yang ditemukan, terdapat kesalahan yang dominan, yaitu kesalahan penambahan sebanyak $43 \%$. Kemudian ditemukan kesalahan pembentukan sebanyak 36\%, penghilangan $17 \%$, dan pengurutan $5 \%$. Kesalahan penambahan menjadi dominan karena ditemukan banyak sekali kata-kata yang tidak seharusnya muncul dalam tulisan yang baik dan benar. Apalagi tidak sesuai dengan kaidah kebahasaan.

Tabel 2. Rekapitulasi Kesalahan Taksonomi dalam Happy Love Guide karya Jose Aditya

\begin{tabular}{llccc}
\hline No & $\begin{array}{c}\text { Kesalahan } \\
\text { Taksonomi }\end{array}$ & $\begin{array}{c}\text { Jumlah Temuan } \\
\text { Kesalahan dalam } \\
\text { Buku }\end{array}$ & $\begin{array}{c}\text { Jumlah Temuan } \\
\text { Kesalahan } \\
\text { Keseluruhan }\end{array}$ & Persentase \\
\hline 1 & Penambahan & 18 & 42 & $43 \%$ \\
2 & Pembentukan & 15 & 42 & $36 \%$ \\
3 & Penghilangan & 7 & 42 & $17 \%$ \\
4 & Pengurutan & 2 & 42 & $5 \%$ \\
\hline
\end{tabular}

Sementara itu, hasil penelitian pada kesalahan ejaan dalam buku pedoman/panduan Happy Love Guide karya Jose Aditya didominasi oleh kesalahan penulisan kata sebanyak $49 \%$. Kemudian ditemukan kesalahan tanda baca sebanyak $0,2 \%$, huruf miring sebanyak $0,11 \%$, huruf kapital sebanyak $0,089 \%$, unsur serapan sebanyak $0,067 \%$, lambang bilangan sebanyak $0,044 \%$, dan $0 \%$ pada pemenggalan kata. Kesalahan penulisan kata menjadi dominan karena ditemukan banyak sekali penulisan atau bentuk dari kata-kata yang digunakan tidak sesuai dengan kaidah kebahasaan, seperti kesalahan pada penulisan kata dasar dan kata bentukan, penulisan pertalian dengan pronomina, penulisan preposisi, penulisan partikel pun dan per. 
Diskursus: Jurnal Pendidikan Bahasa Indonesia

Vol. 3, No. 3, Desember 2020, pp. 240-249

p-ISSN: $2615-4935$

e-ISSN: $2615-4943$

Tabel 3. Rekapitulasi Kesalahan Ejaan dalam Happy Love Guide karya Jose Aditya

\begin{tabular}{llccc}
\hline No & Kesalahan Ejaan & $\begin{array}{c}\text { Jumlah Temuan } \\
\text { Kesalahan } \\
\text { dalam Buku }\end{array}$ & $\begin{array}{c}\text { Jumlah Temuan } \\
\text { Kesalahan } \\
\text { Keseluruhan }\end{array}$ & Persentase \\
\hline 1 & Penulisan Kata & 22 & 45 & $49 \%$ \\
2 & Tanda Baca & 9 & 45 & $0,2 \%$ \\
3 & Huruf Miring & 5 & 45 & $0,11 \%$ \\
4 & Huruf Kapital & 4 & 45 & $0,089 \%$ \\
5 & Unsur Serapan & 3 & 45 & $0,067 \%$ \\
6 & Lambang Bilangan & 2 & 45 & $0,044 \%$ \\
7 & Pemenggalan Kata & 0 & 45 & 0 \\
\hline
\end{tabular}

\section{Pembahasan}

Dari 379 halaman terdapat 87 kesalahan dalam Happy Love Guide karya Jose Aditya. Kesalahan itu terdiri atas 18 kesalahan taksonomi penambahan, 15 kesalahan taksonomi pembentukan, 7 kesalahan taksonomi penghilangan, dan 2 kesalahan taksonomi pengurutan. Sementara itu, kesalahan ejaan terdiri atas 22 kesalahan penulisan kata, 9 kesalahan tanda baca, 5 kesalahan huruf miring, 4 kesalahan huruf kapital, 3 kesalahan unsur serapan, 2 kesalahan lambang bilangan, dan tidak ada kesalahan pada pemenggalan kata. Berikut ini diuraikan analisis data kesalahan taksonomi siasat permukaan dalam Happy Love Guide karya Jose Aditya. Berikut peneliti paparkan analisis data terhadap data yang ditemukan sesuai dengan tujuan penelitian ini.

Data

(1) Kamu pun protes! Kamu jadi penuntut... (hlm. 7)

\section{Analisis}

Kesalahan pada data (1) terletak pada hilangnya kata akan pada frasa" Kamu pun protes." Selain itu, hilangnya konjungsi dan yang menghubungkan antar frasa "Kamu pun protes! Kamu jadi penuntut." Kesalahan terjadi karena ketidakhadiran suatu hal yang seharusnya ada dalam ucapan/tulisan yang baik dan benar sehingga diperlukan perbaikan. Berkenaan dengan itu, Tarigan (2011:149) menyatakan bahwa kesalahan yang bersifat penghilangan ditandai oleh ketidakhadiran suatu butir yang seharusnya ada dalam ucapan yang baik dan benar.

Dari data di atas dapat disimpulkan bahwa kesalahan penghilangan dalam data ini karena hilangnya kata akan dan konjungsi dan.

\section{Data}

(2) Branding saya tidak meningkat! Penjualan tidak meningkat! Panggilan jadi pembicara juga tidak meningkat! It's all the same... (hlm. 32)

\section{Analisis}


Sementara itu, pada data (2) kesalahan terletak pada hilangnya konjungsi dan yang menghubungkan dua kalimat yang setara, yaitu "Branding saya tidak meningkat! Penjualan tidak meningkat!" Selain itu, tidak ada pula konjungsi koordinatif pendamping serta pada kalimat tersebut. Hal itu karena kalimat selanjutnya masih membicarakan peningkatan. Sehingga diperlukan konjungsi pendamping serta untuk menggabungkan semuanya menjadi kalimat utuh. Kesalahan terjadi karena ketidakhadiran suatu hal yang seharusnya ada dalam ucapan/tulisan yang baik dan benar sehingga diperlukan perbaikan. Berkenaan dengan itu, Tarigan (2011:149) menyatakan bahwa kesalahan yang bersifat penghilangan ditandai oleh ketidakhadiran suatu butir yang seharusnya ada dalam ucapan yang baik dan benar.

Dari data di atas dapat disimpulkan bahwa kesalahan penghilangan dalam data ini karena hilangnya konjungsi koordinatif pendamping serta dan konjungsi dan yang menghubungkan dua kalimat.

Rekonstruksi/perbaikan kalimat pada data (1) dan (2) adalah sebagai berikut.

(1a) Kamu pun akan protes dan kamu menjadi penuntut.

(2a) Branding saya tidak meningkat dan penjualan tidak meningkat, serta panggilan jadi pembicara juga tidak meningkat.

Data

(3) Dalam proses panjang saya mempelajari psikologi, NLP (Neuro Language Programming), NAC (Neuro Associative Conditioning), dan Neurosemantics. (hlm. 34)

\section{Analisis}

Pada data (22) kesalahan terdapat pada penggunaan nama ilmiah NLP dan NAC. Peneliti menemukan penulisan ilmiah tersebut tidak menggunakan huruf miring. Padahal dalam penulisan kata ilmiah diperlukan untuk memiringkan kata tersebut. Berkenaan dengan itu, Setyawati (2010:166-168) menyatakan bahwa penggunaan huruf miring hanya boleh digunakan pada penulisan nama buku/majalah/surat kabar, menegaskan atau mengkhususkan huruf, bagian atau kelompok kata, dan nama-nama ilmiah atau ungkapan bahasa asing atau daerah.

Dari data di atas dapat disimpulkan bahwa kesalahan ejaan pada penggunaan huruf miring karena penulisan nama ilmiah tidak dicetak miring.

Data

(4) Tabel di atas adalah versi ringkas dari yang pernah dijelaskan oleh Dr. Robert Lustig dalam bukunya yang berjudul The Hacking of American Mind. (hlm. 48)

\section{Analisis}

Sementara itu, pada data (23) kesalahan pada penulisan judul buku dari Robert Lustig yang tidak menggunakan huruf miring. Padahal dalam penulisan judul buku perlu menggunakan huruf miring. Berkenaan dengan 
itu, Setyawati (2010:166-168) menyatakan bahwa penggunaan huruf miring hanya boleh digunakan pada penulisan nama buku/majalah/surat kabar, menegaskan atau mengkhususkan huruf, bagian atau kelompok kata, dan nama-nama ilmiah atau ungkapan bahasa asing atau daerah.

Dari data di atas dapat disimpulkan bahwa kesalahan ejaan pada penggunaan huruf miring terjadi karena penulisan judul buku menggunakan huruf kecil dan tidak dimiringkan. berikut.

Rekonstruksi/perbaikan kalimat pada data (22) dan (23) adalah sebagai

(22a) Dalam proses panjang saya mempelajari psikologi, NLP (Neuro Language Programming), NAC (Neuro Associative Conditioning), dan Neurosemantics.

(23a) Tabel di atas adalah versi ringkas dari yang pernah dijelaskan oleh Dr. Robert Lustig dalam bukunya ynag berjudul The Hacking of American Mind.

\section{SIMPULAN}

Berdasarkan hasil analisis data dan pembahasan, dapat disimpulkan bahwa terdapat kesalahan taksonomi, yaitu kesalahan taksonomi siasat permukaan sebanyak 42 buah data yang dapat diklasifikasikan sebagai berikut: (1) penambahan sebanyak 43\%, (2) pembentukan sebanyak 36\%, (3) penghilangan sebanyak $17 \%$, dan (4) pengurutan sebanyak 5\%. Kesalahan ejaan, sebanyak 45 buah data yang dapat diklasifikasikan sebagai berikut: (1) penulisan kata sebanyak $49 \%$, (2) penggunaan tanda baca sebanyak $0,2 \%$, (3) penggunaan huruf miring sebanyak $0,11 \%$, (4) penggunaan huruf kapital sebanyak 0,089\%, (5) penggunaan unsur serapan sebanyak $0,067 \%$, (6) penggunaan lambang bilangan sebanyak $0,044 \%$, dan (7) $0 \%$ pada pemenggalan kata. Temuan yang dihasilkan dalam penelitian ini sebanyak 42 buah data pada kesalahan taksonomi siasat permukaan yang didominasi oleh kesalahan penambahan sebanyak $43 \%$ dan 45 buah data pada kesalahan ejaan yang didominasi oleh kesalahan penulisan kata sebanyak 49\%. Meskipun kesalahan taksonomi siasat permukaan lebih sedikit jumlahnya, tetapi mencakup semua kategori. Dalam hal ini, terdapat kesalahan pada empat pembagian menurut taksonomi siasat permukaan. Sementara itu, kesalahan ejaan memiliki jumlah lebih banyak tetapi tidak mencakup seluruh semua kategori. Tidak terdapat satupun data pada pemenggalan kata.

\section{DAFTAR PUSTAKA}

Fraenkel, J. P., \& Wallen, N. E. (2007). How to design and evaluate research in education. New York: McGraw-Hill Compaines, Inc.

Gantamitreka, S. (2016). Kesalahan berbahasa penggunaan EYD. Solo: Genta Smart Publisher. 


\section{Diskursus: Jurnal Pendidikan Bahasa Indonesia}

Vol. 3, No. 3, Desember 2020, pp. 240-249

p-ISSN: 2615-4935

e-ISSN: 2615-4943

Hastuti, S. (2003). Sekitar analisis kesalahan berbahasa Indonesia. Jakarta: Balai Pustaka.

Irianti, P. (1998). Perbedaan handbook danmanual tinjauan isi. Yogyakarta, Universitas Gadjah Mada

Mintowati. (2010). Model-model pembelajaran inovatif. Bandung: PT Remaja Rosdakarya.

Rahayu, M. (2007). Bahasa Indonesia di perguruan tinggi mata kuliah pengembang kepribadian. Jakarta: Grasindo.

Setiyaningsih, dkk. (2014). Tipifikasi kesalahan kebahasaan dalam penulisan skripsi Mahasiswa Universitas Sanata Dharma dan strategi minimalisasinya sebagai upaya pemartabatan bahasa Indonesia (Jurnal Kependidikan). Yogyakarta: Lembaga Penelitian Universitas Sanata Dharma.

Setyawati, N. (2010). Analisis kesalahan berbahasa Indonesia: Teori dan Praktik. Surakarta: Yuma Pustaka.

Sudaryanto. (1993). Metode dan aneka teknik analisis bahasa. Yogyakarta: Gadjah Mada University Press.

Tarigan, H. G. (2011). Pengajaran analisis kesalahan berbahasa. Bandung: Angkasa.

Utomo, A. P. Y. (2008). Pengembangan buku panduan menulis laporan dengan pendekatan konstekstual bagi siswa SD kelas VIII SMP. Skripsi: Universitas Negeri Semarang. 